\title{
Studies on the Caste Differentiation in Termites
}

\author{
III. Emergence of Soldiers and Supplementary Reproductives of the \\ Japanese Termite, Leucotermes (Reticulitermes) speratus (KoLBE)
}

\author{
By Kaoru Shimizu \\ Laboratory of Applied Entomology, Faculty of Agriculture, University of Miyazaki, Miyazaki
}

\section{INTRODUCTION}

The Japanese termite, Leucotermes (Reticulitermes) speratus (KoLBE), is a well known termite species distributing in Japan, Ryukyu and Korea. Northern limit of its distribution in Japan is believed to be Sapporo in Hokkaido. This species is one of the typical damp wood dwellers. Its colonies are small, consisting of individuals less than twenty thousands.

Colonies are commonly found in stumps and stubs, as well as in timbers buried in or laying on the ground and in damp parts of wooden houses.

There are five castes in the colony of Leucotermes (Reticulitermes) speratus: workers, soldiers, macropterous reproductives (queen and king), brachypterous reproductives (supplementary queens and supplementary kings) and apterous reproductives (supplementary queens and supplementary kings).

Many theories have been presented to explain the mechanism of the caste differentiation in termites. These theories can be classified in two categories: one is the theory of intrinsic causes and the other is the theory of extrinsic causes. According to the theories of the first category, the young are not identical in character already at the time of hatching. Some, if not all, castes are distinguishable right from the start of postembryonic life. The castes are predetermined as such within eggs by some intrinsic factors. This intrinsic theory of the caste dif- ferentiation is based primarily on the study of Thompson (1917). If this theory is valid, it follows that the caste of each individual would be predetermined and would not be influenced by any environmental factors. Hare (1934) studied this problem using same species of termite as Tномеson's material and concluded that no conceivable caste predetermination existed among the young nymphs.

The theories of the second category presume that the young are all identical at the moment of hatching, but the differentiation of caste takes place during the postembryonic development under some influence of external factors such as food condition, presence of parasites, care provided from older workers etc. According to recent studies of LÜscheR (1958, 1960), the caste determination is controlled by hormones. After each pseudoergate molt, corpora allata secrete the juvenile hormone which brings the individual into a reactive state of competence for differentiation. $\mathrm{He}$ has also obtained some interesting results with brachypterous nymphs of functional neotenics: when these nymphs underwent a subsequent molt, one out of eleven stayed undifferentiated, one became a neotenic, one soldier-neotenic, and eight others became soldier-nymphs. No such incidence of soldier production occurred in the control.

CAstle (1934) stated that the caste differentiation is due to the environmental factors acting upon the nymphs which possess a potentiality of becoming both

(Received for publication, December 3, 1962) 
alates and soldiers. He also supposed that complicated relationships existed among colony members and thus maintaining the colony balance would be a key factor for a better understanding of caste differentiation problems. Grassé and NoIrot (1958) obtained one replacement soldier by removing the initial soldier from a young colony of a lower termite. Light and WEESNER (1951) observed the second or replacement soldier formation from the second group when the initial soldier among the first young group is removed in incipient colonies of Reticulitermes. Buchli (1956) obtained neotenics in young colonies of Reticulitermes lucifugus despite the presence of primary reproductive pair. Pickens (1932, 1934) noted the exclusion of supernumerary reproductives in coalescent colonies of Reticulitermes hesperus.

As mentioned above, all the recent findings in the termites of Hodotermitidae, Kalotermitidae and Rinotermitidae are conclusively opposing to the intrinsic theory of caste differentiation. It is likely that differentiation of castes was determined by environmental factors. The present paper deals with the results of experiments carried out in our laboratory about the mechanism of the caste differentiation of the Japanese termite, especially of the differentiation of soldiers and supplementary reproductives.

\section{DIFFERENTIATION OF THE SOLDIERS}

\section{Material and Methods}

Winged adults of the Japanese termite nesting in the stump of Japanese cedar on the campus of University of Miyazaki were collected as samples on May 5, 1958. Males and females were separated and put into rearing cages after their wings had been artificially cut off.

For rearing the termites, the agar culture method is generally used. In this study, however, only pine saw-dust was used for feeding the termites. Phials with a capacity of $10 \mathrm{cc}$ served as containers. Each phial was filled with $5 \mathrm{~g}$ of pine saw-dust and loosely plugged with a cotton stopper. Water content of the pine saw-dust was kept at 80 per cent, by adding water when the saw-dust desiccated. One such container with a pair of the Japanese termite (queen and king) formed a 'set'. Two hundreds of such set were prepared for the first series of experiment. These rearing sets were kept in an underground room of the laboratory under shade temperature. At the same time, twenty sets were prepared as the control, and kept under a constant temperature of $25^{\circ} \mathrm{C}$.

The setting was finished on May 10. During successive 10 days, all the sets were inspected every day and dead individuals were removed and replaced. After 10 days, no more replacement was made. Hereafter, observations were made every ten days. Five sets were sampled out every month for detailed examination: eggs and larvae were fixed with F. A. A. (formalin $50 \mathrm{cc}$, acetic acid $50 \mathrm{cc}$, alcohol 50 per cent $900 \mathrm{cc}$ ) solution, larval external structure was examined and the number of their antennal segments was counted under a microscope.

\section{Results and Discussion}

The first emergence of soldiers occurred on August 13, 110 days after the setting. By the time, 188 colonies out of initial 200 had normally developed, three among which contained each one soldier individual. On September 10, 120 days after the setting, soldiers were found in 17 colonies. The mode of further emergence of soldiers is summarized in Table 1.

Although the first emergence of soldiers

Table 1. The number of soldiers emerged in artificial colonies.

\begin{tabular}{lrrrrr}
\hline & Aug. & Sept. & Oct. & Nov. & Dec. \\
\hline Number of soldiers emerged & 3 & 32 & 7 & 2 & 4 \\
Cumulative no. of soldiers & 3 & 35 & 42 & 44 & 48 \\
Number of investigated sets & 188 & 183 & 175 & 170 & 165
\end{tabular}


Table 2. Comparison of external characters between soldiers experimentally obtained in the artificial colonies and those which were collected from the fields.

\begin{tabular}{lcccc}
\hline & $\begin{array}{c}\text { Body length } \\
(\mathrm{mm})\end{array}$ & $\begin{array}{c}\text { Head width } \\
(\mathrm{mm})\end{array}$ & $\begin{array}{c}\text { Pronotum width } \\
(\mathrm{mm})\end{array}$ & $\begin{array}{c}\text { Number of antennal } \\
\text { segments }\end{array}$ \\
\hline Reared soldiers* & 4.40 & 0.80 & 0.52 & 14 \\
Collected soldiers** & 5.10 & 0.94 & 0.68 & 14 \\
$* \quad$ Mean values for 6 individuals. & & & \\
$* *$ Mean values for 10 individuals. & & &
\end{tabular}

Table 3. Number of soldiers emerged in relation to the number of larvae plus workers in the artificial colonies.

\begin{tabular}{lccc}
\hline $\begin{array}{c}\text { Number of larvae plus } \\
\text { workers per colony }\end{array}$ & $\begin{array}{c}\text { Number of } \\
\text { colonies }\end{array}$ & $\begin{array}{c}\text { Number of colonies } \\
\text { in }\end{array}$ & $\begin{array}{c}\% \text { of soldier } \\
\text { emergence }\end{array}$ \\
\hline less than 5 & 53 & 4 & 7.4 \\
5 to 10 & 87 & 24 & 27.6 \\
more than 10 & 25 & 20 & 80
\end{tabular}

occurred on August 13, no colonies sampled out by this time for the detailed observation contained individuals which showed any sign of differentiation toward the soldier formation. Such individuals were first observed among the sample colonies taken out in Septemper. There have been found four individuals with external character of the soldier but with their heads yet milky white in color. These four individuals were counted into the numder of soldiers shown in Table 1.

Table 2 shows the comparison of the external characters between soldiers obtained experimentally and those which were collected from the fields.

As shown in Table 2, every structure of the soldiers obtained from the artificial colonies is considerably smaller than that of the wild soldiers. In contrast to this, the number of antennal segments is always 14 in both groups.

Finally, forty eight soldiers emerged from 48 colonies. There was no colony which yielded more than one soldier. Since the development of incipient colonies with a royal couple proceeded not equivocally, it is interesting to see in which colonies the differentiation of soldiers took place.

The artificial colonies which contained less than five larvae plus workers at the end of the experiment were 53 out of 165 colonies. Soldiers were found only in 4 of these 53 cases. Colonies with more than ten larvae plus workers were 25 out of 165 . Among these 25, soldiers appeared in 20 cases (Table 3 ).

These results seem to indicate that the emergence ratio of the soldiers becomes higher along the increasing numder of larvae plus workers in the colonies and that some minimum number of larvae plus workers may be needed for the induction of soldier emergence. It is also demonstrated that no differentiation of the reproductive caste occurred in such artificial colonies of the Japanese termite within the first year of setting. It follows therefore that, in the artificial colonies, the development of the colony itself is of primary importance for the differentiation of the castes, especially of the soldier.

The time of differentiation is another problem. The clear dissociation of the soldier caste from the worker happens when the number of antennal segments reaches 14. As shown in Table 4, the

Table 4. Number of individuals with various number of antennal segments, in the artificial colonies.

\begin{tabular}{lrrrrrrrr}
\hline $\begin{array}{c}\text { Number of } \\
\text { antennal segments }\end{array}$ & 8 & 9 & 10 & 11 & 12 & 13 & 14 & 15 \\
\hline August & 0 & 9 & 12 & 15 & 54 & 13 & 0 & 0 \\
September & 0 & 0 & 2 & 12 & 43 & 34 & 6 & 0 \\
October & 0 & 0 & 0 & 8 & 37 & 52 & 3 & 0 \\
November & 0 & 0 & 0 & 0 & 48 & 41 & 9 & 0 \\
December & 0 & 0 & 0 & 0 & 11 & 50 & 29 & 10
\end{tabular}


development is much delayed at the stages with 12 and 13 antennal segments. It can be therefore supposed that the most important phase of caste differentiation may be involved in this period of retarded development. This will be also true for the Formosan termite, Coptotermes formosanus SHIRAKI.

\section{DIFFERENTIATION OF THE SUPPLEMENTARY REPRODUCTIVES}

\section{Material and Methods}

Next investigation was undertaken to know the conditions necessary for induction of differentiation of supplementary reproductives in the artificial colonies with varying number of workers, nymphs and larvae. Each colony was settled in a milk bottle filled with $50 \mathrm{~g}$ of sterilized pine saw-dust of 80 per cent water content. All such artificial colonies were kept in a thermostat adjusted at $25^{\circ} \mathrm{C}$ during the experiment. Several groups of varying numbers and combinations were prepared and the mode of appearance of supplementary reproductives was observed.

Experiments and Results

Experiment 1: Four groups were prepared in such a way as shown in Table 5. Preparation was made on August 20, 1961.
Rearing and observation lasted till January of the following year. All the individuals were taken out on February 18 for final examination.

Throughout the rearing period, observation was made every ten days. On September 15, 25 days after the setting, first supplementary reproductives emerged. In three sets of the Worker-and-Nymph group. These individuals were entirely different form both worker and nymph in coloration of their heads. Their heads were light brown and their abdomens were slightly enlarged and light yellow.

No individuals with modified external structure were found in any set of the Worker group. But in the Worker-andLarva group, some individuals were found to have slightly developed wing-buds. The body color of such individuals was milky white in general, and they were easily distinguishable from normal individuals in the sets. The Nymph group showed a high mortality and only 20 individuals survived on October 1.

As shown in Table 5, both supplementary queens and kings appeared in every group. But the ratio of their emergence seems to be considerablly higher in the Worker-and-Nymph group. All the re-

Table 5. Emergence of supplementary reproductives in artificial colonies with varying members.

\begin{tabular}{|c|c|c|c|c|c|c|c|c|c|c|}
\hline \multirow{2}{*}{\multicolumn{3}{|c|}{ Group and set }} & \multicolumn{3}{|c|}{$\begin{array}{l}\text { Starting caste ratio } \\
\text { of the sets }\end{array}$} & \multicolumn{5}{|c|}{$\begin{array}{c}\text { Number of individuals of the castes } \\
\text { observed on Feb. } 18\end{array}$} \\
\hline & & & Worker & Nymph & Larva & $\begin{array}{l}\text { Supple. } \\
\text { queen }\end{array}$ & $\begin{array}{l}\text { Supple. } \\
\text { king }\end{array}$ & Nymph & Larva & Egg \\
\hline $\begin{array}{l}\text { Worker } \\
\text { Worker } \\
\text { Worker } \\
\text { Worker }\end{array}$ & $\begin{array}{l}1 \\
2 \\
3 \\
4\end{array}$ & & $\begin{array}{l}200 \\
200 \\
200 \\
200\end{array}$ & $\begin{array}{l}- \\
- \\
-\end{array}$ & $\begin{array}{l}- \\
- \\
-\end{array}$ & $\begin{array}{r}*- \\
1 \\
2 \\
1\end{array}$ & $\begin{array}{l}- \\
1 \\
1 \\
1\end{array}$ & $\begin{array}{l}- \\
0 \\
0 \\
0\end{array}$ & $\begin{array}{r}\overline{25} \\
35 \\
3\end{array}$ & $\begin{array}{r}- \\
4 \\
20 \\
0\end{array}$ \\
\hline \multicolumn{3}{|c|}{$\begin{array}{ll}\text { Worker-and-Nymph } & 1 \\
\text { Worker-and-Nymph } & 2 \\
\text { Worker-and-Nymph } & 3 \\
\text { Worker-and-Nymph } & 4\end{array}$} & $\begin{array}{l}200 \\
200 \\
200 \\
200\end{array}$ & $\begin{array}{l}10 \\
10 \\
10 \\
10\end{array}$ & $\begin{array}{l}- \\
- \\
-\end{array}$ & $\begin{array}{r}*- \\
3 \\
1 \\
8\end{array}$ & $\begin{array}{l}- \\
2 \\
1 \\
2\end{array}$ & $\begin{array}{l}- \\
4 \\
8 \\
0\end{array}$ & $\begin{array}{l}-\overline{48} \\
20 \\
60\end{array}$ & $\begin{array}{l}\overline{-} \\
25 \\
12 \\
50\end{array}$ \\
\hline \multicolumn{3}{|c|}{$\begin{array}{l}\text { Worker-and-Larva } \\
\text { Worker-and-Larva } \\
\text { Worker-and-Larva }\end{array}$} & $\begin{array}{l}200 \\
200 \\
200\end{array}$ & - & $\begin{array}{l}10 \\
10 \\
10\end{array}$ & $* \frac{2}{1}$ & $\frac{0}{1}$ & $\frac{0}{4}$ & $\frac{0}{15}$ & $\frac{24}{5}$ \\
\hline Nymph & 1 & & - & 200 & - & $*$ & - & - & - & - \\
\hline
\end{tabular}

* All the individuals had perished before inspection. 
Table 6. Emergence of supplementary reproductives in artificial colonies with varying combinations of members.

\begin{tabular}{|c|c|c|c|c|c|c|c|c|}
\hline \multirow{2}{*}{ Group } & & \multicolumn{3}{|c|}{ Starting caste-ratio } & \multicolumn{4}{|c|}{ Results of rearing } \\
\hline & & Worker & Nymph & Larva & Supple. repro. & Nymph & Larva & Egg \\
\hline $50 \mathrm{~W}$ & $\begin{array}{l}1 \\
2 \\
3 \\
4 \\
5 \\
6\end{array}$ & $\begin{array}{l}50 \\
50 \\
50 \\
50 \\
50 \\
50\end{array}$ & $\begin{array}{l}- \\
- \\
- \\
-\end{array}$ & $\begin{array}{l}- \\
\overline{-} \\
- \\
-\end{array}$ & $\begin{array}{l}- \\
- \\
- \\
-\end{array}$ & $\begin{array}{c}\overline{1} \\
\overline{-} \\
1 \\
1\end{array}$ & $\begin{array}{l}- \\
- \\
- \\
-\end{array}$ & $\begin{array}{l}- \\
- \\
- \\
-\end{array}$ \\
\hline $50 W+1 \mathrm{~N}$ & $\begin{array}{l}1 \\
2 \\
3\end{array}$ & $\begin{array}{l}50 \\
50 \\
50\end{array}$ & $\begin{array}{l}1 \\
1 \\
1\end{array}$ & - & $\begin{array}{l}1 \\
1 \\
1\end{array}$ & - & - & $\begin{array}{r}9 \\
12 \\
15\end{array}$ \\
\hline $100 \mathrm{~W}$ & $\begin{array}{l}1 \\
2 \\
3 \\
4 \\
5 \\
6 \\
7\end{array}$ & $\begin{array}{l}100 \\
100 \\
100 \\
100 \\
100 \\
100 \\
100\end{array}$ & $\begin{array}{l}- \\
- \\
- \\
- \\
-\end{array}$ & $\begin{array}{l}- \\
- \\
- \\
- \\
-\end{array}$ & $\begin{array}{l}- \\
- \\
- \\
- \\
-\end{array}$ & $\begin{array}{l}\overline{2} \\
\overline{1} \\
1 \\
-\end{array}$ & $\begin{array}{l}- \\
- \\
\overline{-} \\
\overline{1} \\
-\end{array}$ & $\begin{array}{l}- \\
- \\
- \\
- \\
-\end{array}$ \\
\hline $100 W+10 L$ & $\begin{array}{l}1 \\
2 \\
3 \\
4 \\
5 \\
6\end{array}$ & $\begin{array}{l}100 \\
100 \\
100 \\
100 \\
100 \\
100\end{array}$ & $\begin{array}{l}- \\
- \\
- \\
-\end{array}$ & $\begin{array}{l}10 \\
10 \\
10 \\
10 \\
10 \\
10\end{array}$ & $\begin{array}{c}- \\
\frac{2}{2} \\
\frac{2}{2}\end{array}$ & $\begin{array}{l}1 \\
1 \\
- \\
-1 \\
-\end{array}$ & $\begin{array}{l}- \\
- \\
- \\
-\end{array}$ & $\begin{array}{l}- \\
- \\
\overline{19} \\
10\end{array}$ \\
\hline $200 \mathrm{~W}+10 \mathrm{~N}$ & $\begin{array}{l}1 \\
2\end{array}$ & $\begin{array}{l}200 \\
200\end{array}$ & $\begin{array}{l}10 \\
10\end{array}$ & - & $\begin{array}{l}1 \\
6\end{array}$ & $\underline{2}$ & $\overline{50}$ & $\overline{63}$ \\
\hline $200 \mathrm{~W}+10 \mathrm{~L}$ & $\begin{array}{l}1 \\
2\end{array}$ & $\begin{array}{l}200 \\
200\end{array}$ & - & $\begin{array}{l}10 \\
10\end{array}$ & $\overline{1}$ & $\begin{array}{l}2 \\
1\end{array}$ & - & - \\
\hline
\end{tabular}

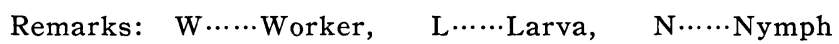

Table 7. Comparison of morphology of supplementary reproductives of different origin.

\begin{tabular}{lccccc}
\hline $\begin{array}{c}\text { Origin of supplementary } \\
\text { reproductives }\end{array}$ & $\begin{array}{c}\text { Body } \\
\text { length } \\
(\mathrm{mm})\end{array}$ & $\begin{array}{c}\text { Head } \\
\text { width } \\
(\mathrm{mm})\end{array}$ & $\begin{array}{c}\text { Pronotum } \\
\text { width } \\
(\mathrm{mm})\end{array}$ & $\begin{array}{c}\text { Wing-bud } \\
\text { length } \\
(\mathrm{mm})\end{array}$ & $\begin{array}{c}\text { Number of } \\
\text { antennal } \\
\text { segments }\end{array}$ \\
\hline $\begin{array}{l}\text { Experimentally obtained from nymphs* } \\
\text { Experimentally obtained from workers** }\end{array}$ & 5.33 & 0.92 & 0.876 & 0.705 & 15 and 16 \\
Collected from the field & 5.90 & 0.96 & 0.790 & -*** & 15 and 16 \\
$*$ Mean values for 10 individuals. & & 0.95 & 0.850 & 0.760 & 16 \\
$* *$ Mean values for 5 individuals. & & & & \\
$* * *$ & & & &
\end{tabular}

productives differentiated possessed full reproductive ability yielding eggs and larvae.

Experiment 2: In this experiment, the number of individuals of the component castes was changed as in Table 6. Preparation was made on September 20, 1961, and rearing lasted till January, 1962.

Among the groups containing workers alone, only one supplementary reproduc- tive emerged in a set of the $100 \mathrm{~W}$ group. Taking in account that in Experiment 1 , the emergence of supplementary reproductives occurred in every set of 200 workers, it seems likely that the frequency of emergence of supplementary reproductives increases with the increase of number of workers in the colony.

Among the groups containing workers and nymphs, the emergence of supple- 
mentary reproductives was observed both in the $50 \mathrm{~W}+1 \mathrm{~N}$ group and in the $200 \mathrm{~W}+$ $10 \mathrm{~N}$ group. In former group, all the nymphs developed into supplementary reproductives. Emergence of supplementary reproductives also occurred in worker + larva groups $(10 \mathrm{~W}+10 \mathrm{~L}, 200 \mathrm{~W}+$ 10L). But careful examination of the table seems to suggest that the emergence of supplementary reproductives takes place easiest from the nymphs origin. In addition, there are remarkable morphological differences among the supplementary reproductives of different origin. Those of worker origin have no wingbuds and have less developed thorax when compared with those of nymphal origin (Table 7).

\section{CONCLUSION}

The results of these experiments support the extrinsic theory of caste differentiation in the Japanese termite. Differentiation of soldiers and supplementary reproductives is conditioned by the development or construction of the artificial colonies. A certain number seems to be necessary for induction of the soldier differentiation in artificial colonies containing workers alone. Nymphs are most capable of developing supplementary reproductives although the latter can be produced from larvae as well as from workers. From our previous works and present experiments, it is possible to make a diagram of the caste differentiation in the Japanese termite (Fig. 1). This is a diagram of the differentiation potency, for the normal differentiation in the normal colonies takes place along the left-hand line.

\section{SUMMARY}

The Japanese termite was used for study of the caste differentiation of termites, particularly of the differentiation of soldiers and supplementary reproductives.

Emergence of soldiers was examined in 200 experimental colonies starting each with a royal couple, and some relation between the emergence of soldiers and the number of larvae plus workers was noticed. Soldiers appeared in only 4 out 53 artificial colonies containing less than 5 larvae plus workers, the emergence ratio, 7.4 per cent. Among the 25 colonies containing more than 10 larvae plus workers, on the contrary, 20 colonies yielded soldiers. Ratio of soldier emergence reached 80 per cent here. It follows therefore that the emergence ratio of soldiers increases with the number of larvae plus workers in the colonies and a certain number of larvae plus workers is needed for the initiation of soldier differentiation.

Another series of experiments demonstrated that the supplementary reproductives could develop either from larvaworkers or nymphs, but most frequently from nymphs combined with considerable numbers of workers.

From these results it can be concluded

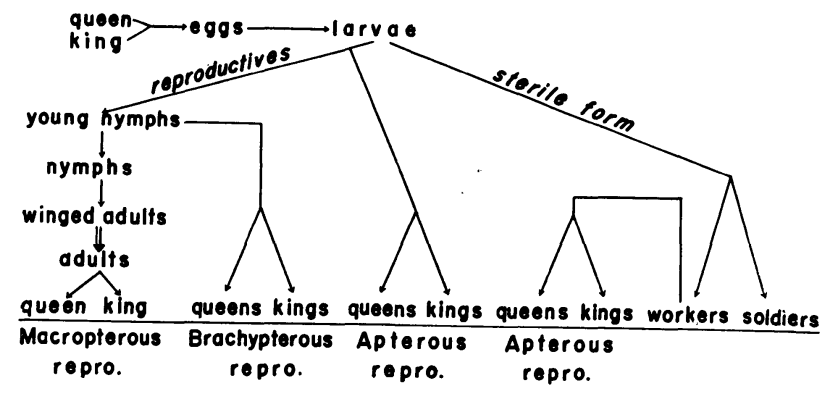

Primary repro. Socondary repro. Tertiary repro. Tortiory repro.

Fig. 1. Caste differentiation in the Japanese termite. 
that the caste differentiation in the Japanese termite is easily influenced by the construction of members in the colonies. From the result, a diagram of the caste differentiation in the Japanese termite was made.

\section{ACKNOWLEDGMENTS}

The author wishes to express his gratitude to Prof. S. Nakajima of the Laboratory of Applied Entomology, Faculty of Agriculture, University of Miyazaki, for his constant directions and encouragement, and for the critical reading of the manuscript. Thanks are also due to $\mathrm{Mr}$. Y. Nakajima of the same Laboratory for his assistance during this work.

\section{REFERENCES}

Buchli, H. (1956) Bull. Union Internat. Etude
Insectes Sociaux 3: 132 143.

Castle, G. B. (1934) Termites and termite control (Edited by Koford et al.) Univ. Calif. Press, 273 310.

Grassé, P. P. and C. Noirot (1958) C. R. Acad. Sci., Paris 264: 1789 1795.

HARE, L. (1934) Jour. Morph. and Physiol., Philadelphia 56: $267 \sim 293$.

Light, S. F. and F. M. WeEsner (1951) Jour. Exp. Zool. 117: 397 414.

LüscheR, M. (1958) Naturwissenschaften 45: 66〜 70.

Lüscher, M. (1960) Ann. New York Acad. Sci. 89: $549 \sim 563$.

Pickens, A. L. (1932) Pan-Pacific Ent. 8: 178 180.

Pickens, A. L. (1934) Termites and termite control (Edited by Kofold et al.) Univ. Calif. Press, 164 172.

Thом pson, C. B. (1917) Jour. Morph. 30: 83 136.

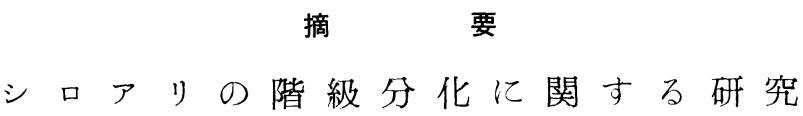

第 3 報 ヤマトシロアリの兵蟻及び副生殖虫の発現

清水薰

宮崎大学農学部応用昆虫学研究室

ヤマトシロアリの兵蟻と副生殖虫の出現についてみる と, 王・娃の 1 対からの人工コロニ一において, 幼虫 と, 職蟻が 5 頭以下出現した人エコロニーの 53 個のう ち 4 個にだけ兵蟻が現われ， $7.4 \%$ の出現率であった。 幼虫と, 職蟻が 10 頭以上出現したコロニ一では, 兵蟻が 認められたのは 25 個のうち 20 個で 80\% であった。 すなわち幼虫之職蟻の個体数が多くなるほど，兵蟻の出
現率は高くなる。副生殖虫についていえば，多くの副女 王・副王が職蟻やニンフのグループから 発現した。ま た 50〜200 頭職蟻区の間において, 職蟻の個体数が多い ほど，副生殖虫の発現は容易であった。これらの実験の 結果から, ヤマトシロアリの階級分化は, コロニ一を構 成している個体数に，容易に影響されることがわかっ た。 